\title{
El bileğinin distal radyoulnar eklem dışı sorunları
}

\author{
Wrist problems other than distal radioulnar joint
}

\author{
Mehmet Şükrü Şahin, Mehmet Barış Sargın, Kemal Gökkuş
}

Başkent Üniversitesi Tıp Fakültesi, Ortopedi ve Travmatoloji Ana Bilim Dalı, Alanya, Antalya

Ulnar taraf el bilek ağrısı nadir görülmesine rağmen hastanın el bilek fonksiyonlarını kısıtlayan bir durumdur. Bu sorunlar yaşam kalitesini bozarak, günlük yaşam aktivitelerini gerçekleştirirken zorlanmalara neden olmaktadır. Ulnar taraf el bilek ağrısının en sık sebebi distal radyoulnar ekleme ait sorunlardır. Distal radyoulnar eklem dışı sorunlar temel olarak tendinopatiler, kemik ve eklem patolojileri, tümör ve tümör benzeri oluşumlar, enflamatuvar hastalıklar ve nörovasküler hastalıklar olarak sınıflanabilir. Distal radyoulnar eklem dışı patolojilerin çoğu istirahat, soğuk uygulama, steroid olmayan anti-enflamatuvar ilaçların kullanımı, aktivite modifikasyonu ve fizik tedavi modaliteleri gibi cerrahi dışı yöntemlerle tedavi edilebilir. Cerrahi dışı yöntemlerin başarısız olduğu durumlarda nedene yönelik cerrahi tedavi seçenekleri mevcuttur. Tanının zamanında koyularak doğru tedavinin uygulanması, hastanın günlük işlerine dönebilmesi ve yaşam kalitesinin artırılması için önemlidir. Günlük pratikte karşılaşılabilecek bu hastalıkların etiyolojisi, klinik seyri, tanı ve tedavi yöntemlerinden bir bütünlük içerisinde kısa kısa bahsedilerek yararlı bir farkındalık yaratılması amaçlanmıştır.

Anahtar sözcükler: ulnar tünel sendromu; ulnar sıkışma sendromu; Kienböck hastalığı; ulnar el bilek ağrısı; tendinopati

\footnotetext{
U
} Inar taraf el bilek ağrısı sık görülen ve hastanın el bilek fonksiyonlarını kısıtlaması ve yaşam kalitesini bozması nedeniyle önemli bir klinik tablodur. Bu bölgenin ağrısı sinsi başlangıçlı olması, kronik seyri ve günlük aktiviteleri gerçekleştirirken zorlanmaya sebep olmasından dolayı sıklıkla bel ağrısına benzetilir. Distal radyoulnar eklem (DRUE) dışı sorunlar temel olarak tendinopatiler, kemik ve eklem patolojileri, tümör ve tümör benzeri oluşumlar, enflamatuvar hastalıklar ve nörovasküler patolojiler olarak sınıflanır. Doğru tanının zamanında koyularak tedavi edilmesi, hastanın günlük aktivitelerine dönebilmesi ve yaşam kalitesinin artırılması için önemlidir.
Although rarely seen, ulnar sided wrist pain is a condition which limits patient's wrist functions. These problems usually disrupt the quality of life and cause difficulties in performing daily activities. Distal radioulnar joint problems are the most common cause of ulnar sided wrist pain. Wrist problems other than distal radioulnar joint can be classified as tendinopathies, bone and joint pathologies, tumors and tumor-like lesions, inflammatory conditions and neurovascular diseases. Most of these pathologies can be treated nonoperatively by rest, cold application, nonsteroidal antiinflammatory drugs, activity modification and different physical therapy modalities. Surgical treatment is the preferred treatment option for the cause-oriented treatment. It is very important to make right diagnosis and make correct treatment timely for the patient in order to return to their daily work and to increase the quality of life. In this review, we emphasized the most important and common distal radioulnar extra-articular wrist problems. It is aimed to create a useful awareness by briefly mentioning the etiology, clinical course, diagnosis and treatment methods of these diseases which can be encountered in our daily practice.

Key words: ulnar tunnel syndrome; ulnar impingement syndrome; Kienbock's disease; ulnar sided wrist pain; tendinopathy

\section{TENDINOPATILER}

\section{Ekstansör Karpi Ulnaris Tendinopatisi}

Ulna kemiğinin distalinde ekstansör karpi ulnaris (EKU) sürtünmeye karşı sinovyal bir membranla korunarak fibro-osseöz bir tünel olan 6. ekstansör kompartmandan geçer. EKU tendonuna stabilite sağlamak için 6. ekstansör kompartman, kalın periostla döşeli bir oluk olan ulnar sulkusun üstünü örter. Ulnotrikuetral eklem aralığı seviyesinde EKU kılıfı sonlanır. Bu seviyeden itibaren EKU tendonu ekstansör retinakulum tarafından örtülür (Şekil 1). ${ }^{[1]}$

\footnotetext{
- Iletişim adresi: Doç. Dr. Mehmet Şükrü Şahin, Başkent Üniversitesi Tıp Fakültesi, Ortopedi ve Travmatoloji Ana Bilim Dalı, Alanya, Antalya Tel: 0533 - 3575275 e-posta: msukrusahin@yahoo.com

- Gelis tarihi: 5 Mayıs $2021 \quad$ Kabul tarihi: 19 Mayıs 2021
}

ORCID iD: Mehmet Şükrü Şahin, 0000-0001-7677-8423 • Mehmet Barış Sargın, 0000-0003-4648-9473 • Kemal Gökkuş, 0000-0002-4916-3471 


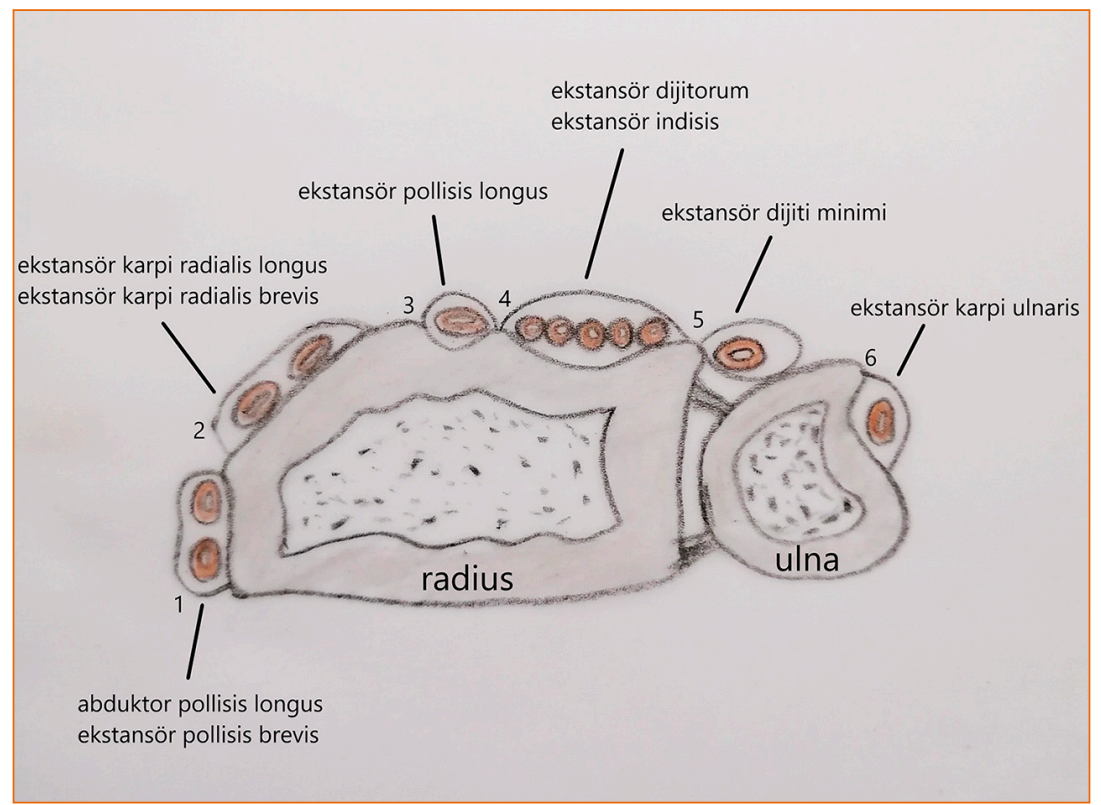

Şekil 1. Ekstansör kompartmanlar.

Ekstansör karpi ulnaris tendinopatileri temelde tendinozis ve stenozan tenosinovit olarak ikiye ayrilır. Uzun süreli tekrarlayan pronasyon-supinasyon stresine yanıt olarak tendonda kalınlaşma, kan akımında azalma, yer yer yarılmalar ve reaktif tenosinovit görülür. Bu durum tendinozis olarak adlandırılır. Tendon kılıfının kalınlaşması, kabalaşması ve kronik enflame görünümü ise stenozan tenosinovit olarak isimlendirilir. ${ }^{[1]}$

Altıncı ekstansör kompartmanın tenosinoviti 1. ekstansör kompartmandan sonra en sık görülen tenosinovittir. ${ }^{[2]}$ Ulnar taraf el bilek ağrısının sık görülen nedenlerinden birisidir. ${ }^{[3]}$ Fizik muayenede EKU trasesinde hassasiyet ve bazen şişlik mevcuttur. Ön kol pronasyondayken dirence karşı ulnar deviasyon ve ön kol supinasyonda iken dirence karşı el bilek ekstansiyonu hareketlerinde ağrı görülür. EKU sinerji testi, EKU tendiniti ve eklem içi patolojilerin ayrımını yapmada başarılıdır. ${ }^{[4]}$ Bu testte hastanın dirseği $90^{\circ}$ fleksiyonda, ön kolu supinasyonda, el bileği nötral pozisyonda dururken muayeneyi yapan hekim bir eliyle hastanın başparmağı ve üçüncü parmağını tutarak diğer eliyle EKU tendonunu palpe eder. Hastadan dirence karşı başparmağını radyal deviasyona alması istenir. Bu hareketle EKU trasesinde ağrı olması EKU tendiniti açısından anlamlıdır (Şekil 2). ${ }^{[1]}$ Tanıya yönelik konvansiyonel radyografi, ultrasonografi ve manyetik rezonans (MR) görüntüleme yöntemleri kullanılabilir.

Ekstansör karpi ulnaris tendinopatileri genelde konservatif tedaviye iyi yanıt verir. Yaklaşık üç hafta süreyle ön kol pronasyonda, el bilek hafif ekstansiyon ve ulnar deviasyonda kısa kol atel uygulaması ve steroid olmayan anti-enflamatuvar ilaçların kullanımı ile birlikte fizyoterapi desteğiyle şikâyetler büyük oranda kaybolur. Semptomların devamı halinde EKU tendon kılıfına kortikosteroid enjeksiyonu denenebilir. Cerrahi dışı tedavilere yanıt alınamayan dirençli olgularda 6. ekstansör kompartmanın cerrahi gevşetmesi uygulanabilir ve bu yöntemle başarılı sonuçlar bildirilmiştir. ${ }^{[5,6]}$

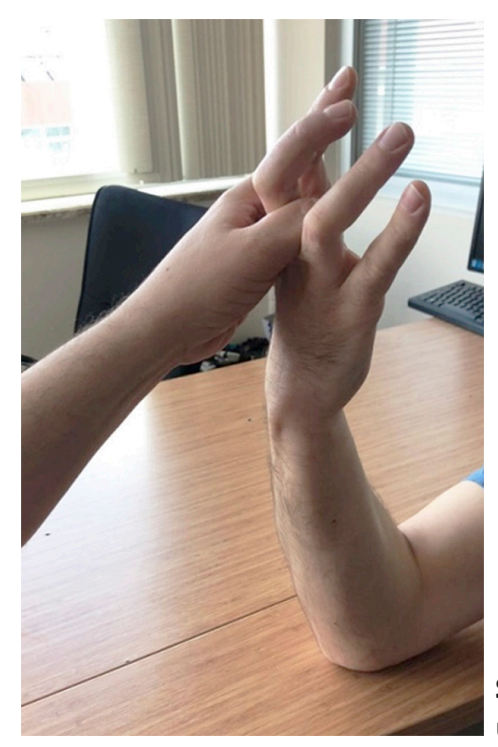

Şekil 2. Ekstansör karpi ulnaris (EKU) sinerji testi. 


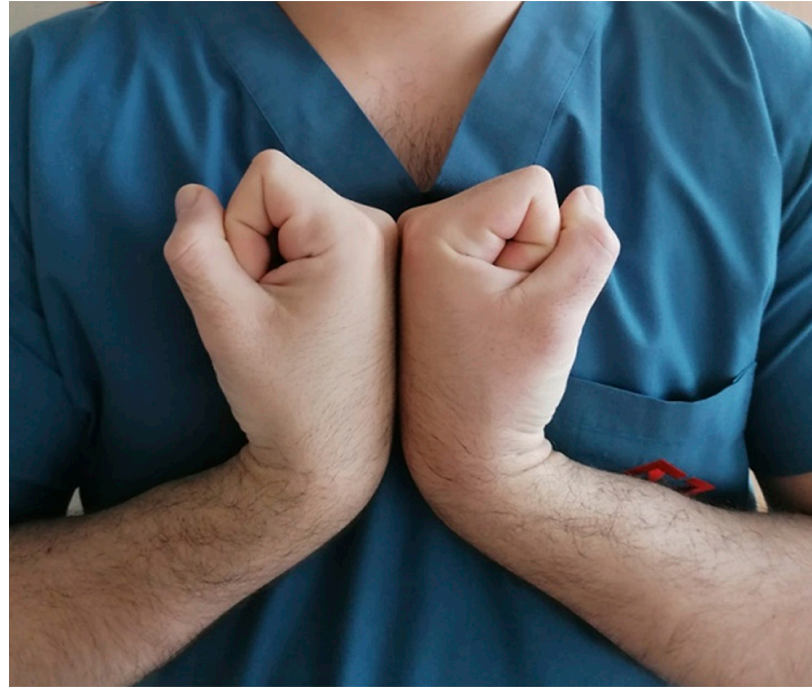

Şekil 3. Kalp testi. Her iki el bileğinin fleksiyon - supinasyon ulnar deviasyon pozisyonuna dikkat ediniz.

\section{Ekstansör Karpi Ulnaris Tendon Subluksasyonu ve Dislokasyonu}

Ekstansör karpi ulnaris subluksasyonu veya dislokasyonu ulnar taraf el bilek ağrısıyla başvuran hastada ayırıcı tanıda akılda tutulmalıdır. Normal popülasyonda nadiren görülen bu yaralanmalar daha çok raket ve sopa sporlarıyla uğraşan sporcularda görülür. EKU tendon kılıfının tam kat yırtılması için ön kol supinasyonda, el bilek fleksiyon ve ulnar deviasyonda iken ani EKU kontraksiyonu gerekir. Bu hareket sonrası, özellikle ulnar oluk normalden daha sığ ise EKU tendonu palmar-mediale yönelerek disloke olur. ${ }^{[7]}$

Akut dislokasyonda fizik muayenede ulnar taraflı el bilek ağrısı ve hafif şişlik görülür.

Kronik semptomatik EKU subluksasyonu olan hastalar supinasyon ve ulnar deviasyon hareketi esnasında el bileğinin dorsal-ulnar tarafında ağrılı bir atlama şikâyetiyle başvururlar. Fizik muayene esnasında subluksasyon görülebilir ve palpe edilebilir. ${ }^{[8]}$ Sublukse olan tendon "kalp testi" ile gösterilebilir. Bu testte hastadan her iki el bileği fleksiyonda ve ön kollar supinasyonda iken ellerini ulnar kenarları göğse bastıracak şekilde sırt sırta birleştirmesi istenir. Bu pozisyonda ellerin duruşu bir kalbi andırdığı için test bu ismi almıştır (Şekil 3). Çoğu EKU instabilitesinde bu test belirgin bir ses ve atlama hissiyle birlikte pozitiftir. ${ }^{[1]}$

Dinamik MR ön kol rotasyonuyla birlikte EKU subluksasyonu/dislokasyonunu gösterebilir, aynı zamanda MR, EKU oluğunun morfolojisini ve varsa eşlik eden patolojileri göstermesi açısından önemlidir. ${ }^{[9]}$
Akut yaralanmaların tedavisinde tendon kompartmanına açık olarak yerleştirildikten sonra tendon kılıfının onarımı ile el bilek radyal deviasyon ve pronasyonda en az altı hafta immobilizasyon önerilmektedir. ${ }^{[1]}$

Kronik dislokasyonlarda tendonun açık olarak redüksiyonu ve kılıfın rekonstrüksiyonu gerekir. Patolojiye göre transosseöz sütürler kullanılarak periostun tekrar yerleştirilmesi, osteofibröz kılıfın primer onarımı ya da retinakular serbest flep kullanılarak rekonstrüksiyonu gibi tedavi seçenekleri mevcuttur. ${ }^{[8]}$

\section{Fleksör Karpi Ulnaris Tendinopatisi}

Fleksör karpi ulnaris (FKU) tendinopatisi genelde aşırı kullanıma bağlı, sinsi başlangıçlı ağrıyla bulgu verir. Fizik muayenede FKU tendonunun pisiforma yapışma yerinin yaklaşık $2-3 \mathrm{~cm}$ proksimalinde hassasiyet mevcuttur. Dirence karşı fleksiyonda ve ulnar deviasyonda ağıı görülür. Eşlik eden ulnar sinir semptomları görülebilir. ${ }^{[10]}$

Tedavi sıklıkla istirahat, immobilizasyon, steroid olmayan anti-enflamatuvar ilaçların kullanımı ve nadiren kortikosteroid enjeksiyonunu içeren cerrahi dışı tedavidir.

Fleksör karpi ulnaris ve palmaris longus dışındaki el bilek tendonlarında en sık görülen problem stenozan tenosinovittir. FKU tendonunda sinovyal kılıf olmadığı için stenozan tenosinovit görülmez. Ağrının kaynağı intrinsik dejeneratif değişikliklerdir. Tendinozistendinit ayrımı tedavide de önem arz etmektedir. Tendinoziste enflamasyon görülmediği için steroid olmayan anti-enflamatuvar ilaçların kullanımı ve lokal kortikosteroid enjeksiyonları geçici rahatlama sağlasa da uzun dönemde kanıtlanmış etkinlikleri yoktur. Esas problem dejenerasyon olduğu için cerrahi dışı tedavide rotator kılıf tendinozisi ve lateral epikondilitte olduğu gibi germe ve güçlendirme egzersizleri denenmelidir. Bu tedavi başarısız olduğunda cerrahi olarak debridman ve uç uca onarım planlanabilir. ${ }^{[11]}$

\section{KEMIK VE EKLEM PATOLOJiLERi}

\section{Ulnar Stiloid İmpaksiyon Sendromu}

Ulnar stiloid impaksiyon sendromu (USiS) ulnokarpal impaksiyondan farklı ve daha nadir görülen bir durumdur. USiS normal anatomik varyant olarak veya geçirilmiş travma sonrası stiloidin yanlış kaynaması ya da kaynamamasına bağlı normalden uzun stiloide sahip kişilerde görülür. Ulnar stiloid trikuetruma impakte olarak ulnar taraflı el bilek ağrısına sebep olur.

Ulnokarpal impaksiyondan farklı olarak nötral ya da negatif ulnar varyansa sahip hastalarda görülür. ${ }^{[12]} A$ ğrı özellikle ekstansiyon ve supinasyonda fazladır. Fizik 


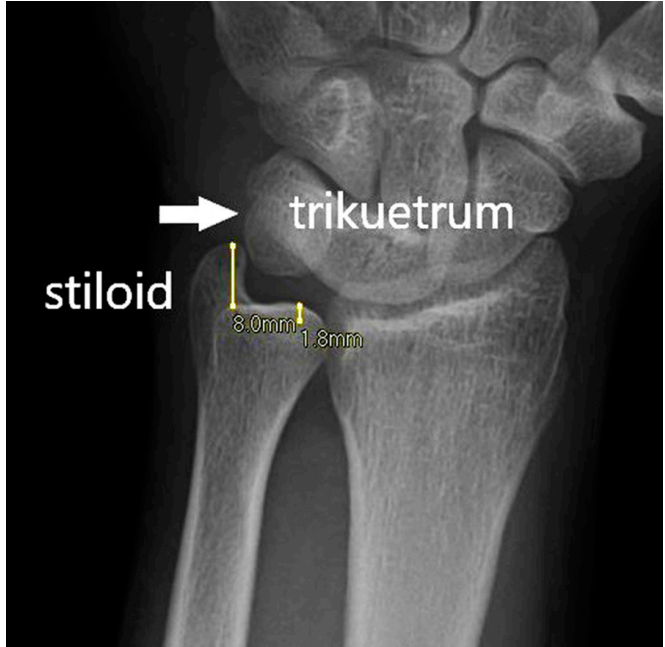

Şekil 4. Ulnar stiloid impaksiyon sendromu önarka grafisi. Ulna stiloidi ile trikuetrum arası mesafenin azaldığı görülüyor (ok).

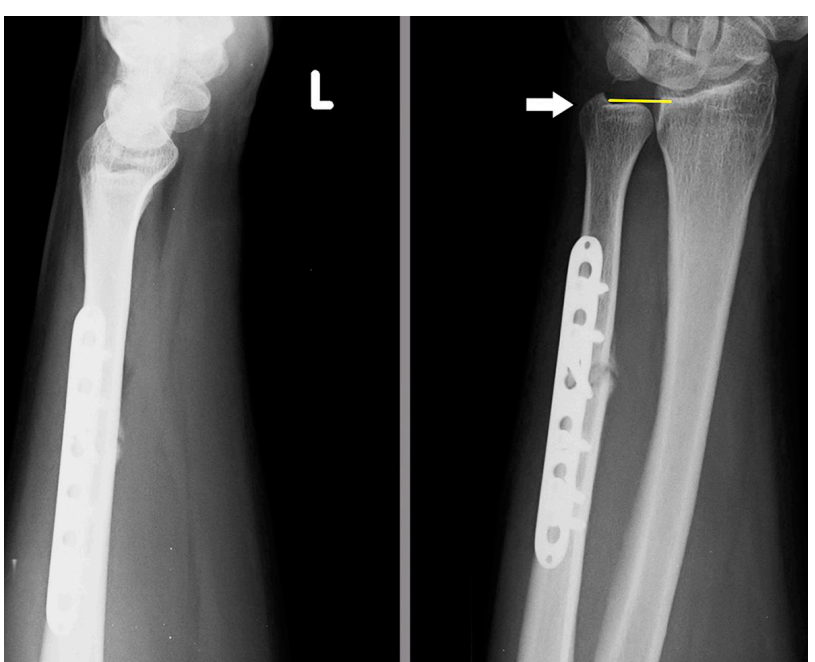

Şekil 5. Ulnar kısaltma osteotomisi + kısmi stiloidektomi (ok) uygulanmış hastanın ameliyat sonrası direkt grafisi. Ulnar varyansın düzeldiğine dikkat ediniz (çizgi). muayenede ulnar stiloid üzerinde palpasyonla hassasiyet mevcuttur. El bilek tam ekstansiyonda iken ön kola maksimum supinasyon yaptırılınca ağrı olması tanı koymakta yardımcı olur. ${ }^{[13]}$

USis klinik bir tanı olmakla birlikte doğrulamak için direkt radyografi ve MR görüntüleme kullanılabilir. Direkt grafilerde ulna stiloidi ve trikuetrum arasındaki mesafenin azalması (Şekil 4), ulna başının düzleşmesi, subkondral skleroz ve kistler, ulnar stiloidde kaynamama ve eklem fareleri görülebilir. MR görüntüleme ulnar stiloid ve trikuetrumdaki kemik ödemi ve kistik değişiklikleri radyografiden daha erken dönemde gösterir. ${ }^{[14]}$

Cerrahi dışı tedavi aktivite modifikasyonu, immobilizasyon, steroid olmayan anti-enflamatuvar ilaçların kullanımı ve kortikosteroid enjeksiyonunu içerir. Cerrahi dışı tedaviye yanıt alınamayan olgularda triangular fibrokartilaj kompleksi (TFKK) yapışma yerine zarar vermeden tam ya da kısmi stiloidektomi gerekebilir. ${ }^{[12]}$

Bazen ulnar impaksiyon sendromu ve ulnar stiloid impaksiyon sendromu birlikte görülebilir. Tedavide ulnar kısaltma ve kısmi stiloidektomi birlikte uygulanır (Şekil 5).

\section{Hamatolunat İmpaksiyon Sendromu}

Hamatolunat impaksiyon, ulnar taraf el bilek ağrısının nadir nedenlerinden biridir. Hamat kemik ile lunat kemik arasında eklem yüzü bulunması (tip 2 lunat kemik) hamat kemiğin proksimal kısmında kondromalaziye neden olur. Bileğin tam ulnar deviasyonda kullanılmasının bu iki kemik arasında sıkışma ve sürtünmeyi artırarak kondromalaziye yol açtığı düşünülmektedir. ${ }^{[15]}$ Ulnar taraf el bilek ağrısı olan hastada direkt grafilerde tip 2 lunat saptanması durumunda şikâyetin muhtemel sebebinin hamatumun proksimal polündeki artroz olabileceği akılda tutulmalıdır. MR görüntüleme kondromalazinin erken evreleri için düşük sensitiviteye sahiptir ama hamatumun proksimal polündeki kemik ödemi, skleroz ve subkondral kistler gibi kondromalazi ve fokal osteoartritin sekonder işaretlerini saptayabilir. Hamatumun proksimal polünün artroskopik olarak traşlanması karpal mekaniği etkilemeden semptomlarda rahatlama sağladığı için tercih edilen cerrahi tedavi yöntemidir. ${ }^{[16]}$

\section{Ulnar Impingement Sendromu}

Ulnar impingement sendromu kısalmış distal ulnanın sigmoid çentiğin proksimalinde distal radiusa sıkışmasına bağlı olarak meydana gelen, ağrılı psödoartroza neden olan bir durumdur. En sık olarak distal ulna rezeksiyonunu içeren cerrahi prosedürler sonrası görülmekle birlikte, konjenital ya da erken ulnar büyüme plağı kapanmasına bağlı olarak da görülebilir. Negatif ulnar varyans, tekrarlayan supinasyon ve pronasyon hareketlerine bağlı olarak ulna ile distal radiusun proksimal ulnar kısmı arasında anormal temasa neden olur.

Hastalar el bileğinde ağrı, kavramada güçlük, pronasyon ve supinasyonda klik hissinden şikâyetçidir. Fizik muayenede radius ve ulnaya birlikte kompresyon uygulandığında ağrı meydana gelir. Pronasyon ve supinasyonda ağrılı bir klik oluşur. Ağrı özellikle 


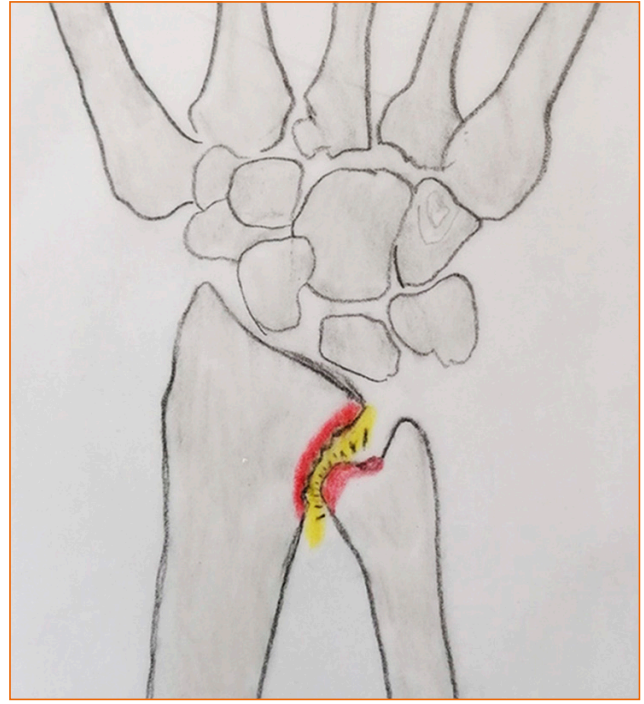

Şekil 6. Ulnar impingement sendromu. Sigmoid çentiğin proksimalindeki eroziv lezyonlara ve radyoulnar konverjansa dikkat ediniz.

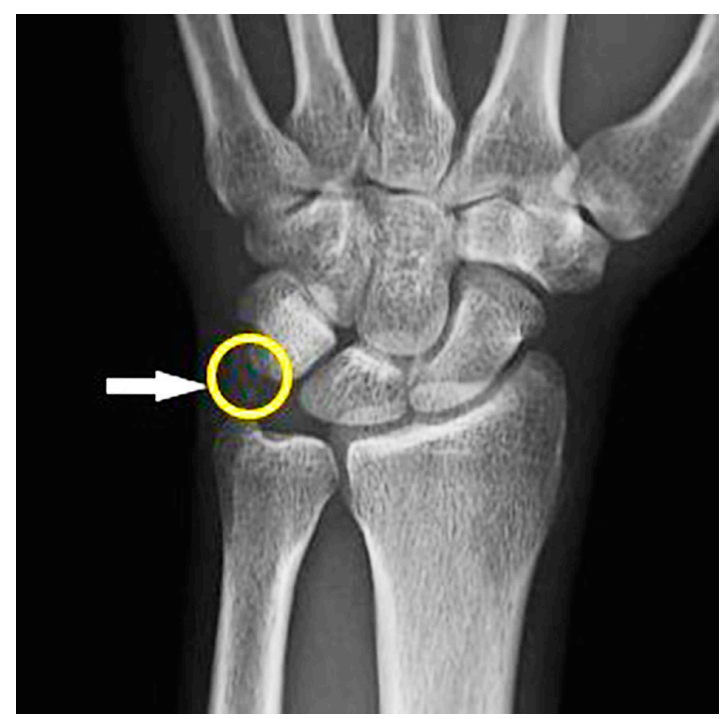

Şekil 7. Ekstansör karpi ulnaris (EKU) kalsifik tendiniti. Ulna stiloidi distali ve pisiform proksimali arasındaki kalsifikasyon (ok). dirence karşı supinasyonda artar. Pronasyonda distal ulna ön-arka planda instabildir. Kavrama gücü azalmıştır. ${ }^{[17]}$ Direkt grafilerde distal radiusun sigmoid çentiğin proksimalinde kalan ulnar tarafında kemik hipertrofisi ve tarak şeklinde görülen eroziv ve proliferatif lezyonlar mevcuttur (Şekil 6). Ayrıca radius ve ulnanın koronal planda birbirine yaklaşmasını tanımlayan radyoulnar konverjans görülür. $M R$ ve direkt grafi bulguları belirginleşmeden, etkilenen seviyede distal radius ve ulnada skleroz ve kemik ödemini gösterebilir. ${ }^{[16]}$ Cerrahi tedavide ekstansör karpi ulnaris tenodeziyle stabilitenin sağlanması, ulnar uzatma ya da radyal kısaltma uygulanabilir. ${ }^{[17]}$

\section{Nondisosiyatif Karpal İnstabilite}

Nondisosiyatif karpal instabilite (Carpal Instability Nondissociative, CIND) tüm proksimal karpal sıranın radyokarpal, midkarpal ya da her iki eklemi ilgilendiren disfonksiyonuna verilen isimdir. Bir karpal sıradaki kemikler arasındaki instabilite disosiyatif karpal instabilite (Carpal Instability Dissociative, CID) olarak adlandırılır. ${ }^{[18]}$ Direkt grafilerde proksimal sıradaki kemikler arasında ayrışma ya da bu kemiklerde kırık olmamasıyla disosiyatif karpal instabiliteden ayrılabilir.

Nondisosiyatif karpal instabilite dört ana grupta incelenebilir: Palmar CIND (CIND- volar intercalated segment instability, VISI), Dorsal CIND (CIND- volar intercalated segment instability, DISI), Kombine CIND ve Adaptif CIND. Hepsinde ortak olarak el bilek radyal deviasyondan ulnar deviasyona gelirken ağrılı klik görülür. ${ }^{[18]}$
Tüm CIND'lerde başlangıç tedavisi cerrahi dışı tedavidir. Steroid olmayan anti-enflamatuvar ilaçlar ve aktivite modifikasyonu genelde semptomları azaltır. Kliniğin durumuna göre tedaviye propriyosepsiyon eğitimi, splintleme ve fizyoterapi eklenebilir. Cerrahi dışı tedaviye yanıtsız olgularda cerrahi gündeme gelir.

\section{Kalsiyum Depolama Hastalığı}

Kalsiyum depolama hastalığı, kalsifik periartrit, kalsifik tendinit, kalkaröz tendinit ve peritendinitis kalkarea olarak da adlandırılan, eklem ve çevre dokulara kalsiyum hidroksiapatit kristali depolanmasıyla karakterize bir hastalıktır. El ve el bileği çevresinde nadir görülür, ancak enfektif durumlar, kristal ve enflamatuvar artropatilerle karışabilmesi açısından akılda tutulmalıdır.

El bilek çevresinde en sık görüldüğü bölge fleksör karpi ulnaris tendonu insersiyosudur. Genel olarak standart iki yönlü grafiler tanı için yeterlidir, ilk grafilerde patoloji saptanmazsa oblik grafiler çekilebilir. Depozitler tipik olarak dens, homojen, kortikal veya trabeküler patern oluşturmayan amorf görünümdedir (Şekil 7). Bu görünüm heterotopik ossifikasyondan ayrılmasında yardımcı olur.

Tedavide ilk aşamada cerrahi dışı yöntemler seçilmelidir. Hastalık kendisini sınırlayan yapıda olduğu için akut dönemde steroid olmayan anti-enflamatuvar ilaçlar, atel uygulaması ve aktivite modifikasyonu denenmelidir. Cerrahi, medikal tedaviye yanıtsız veya tekrarlayan lezyonlar için saklanmalıdır. ${ }^{[19]}$ 


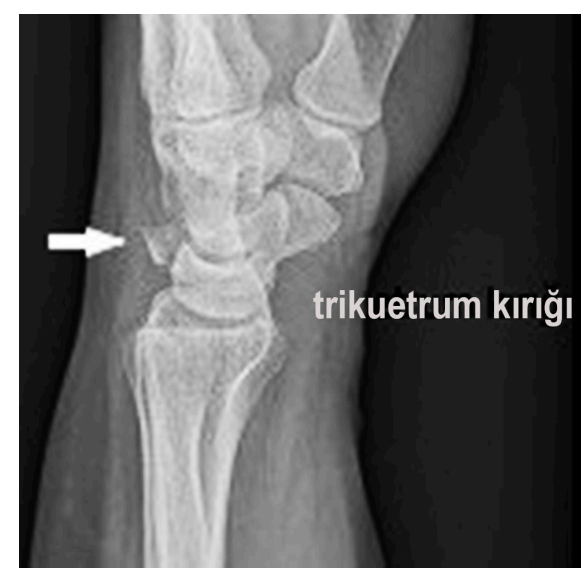

Şekil 8. Trikuetrum dorsal kortikal kırı̆̆ı (ok).

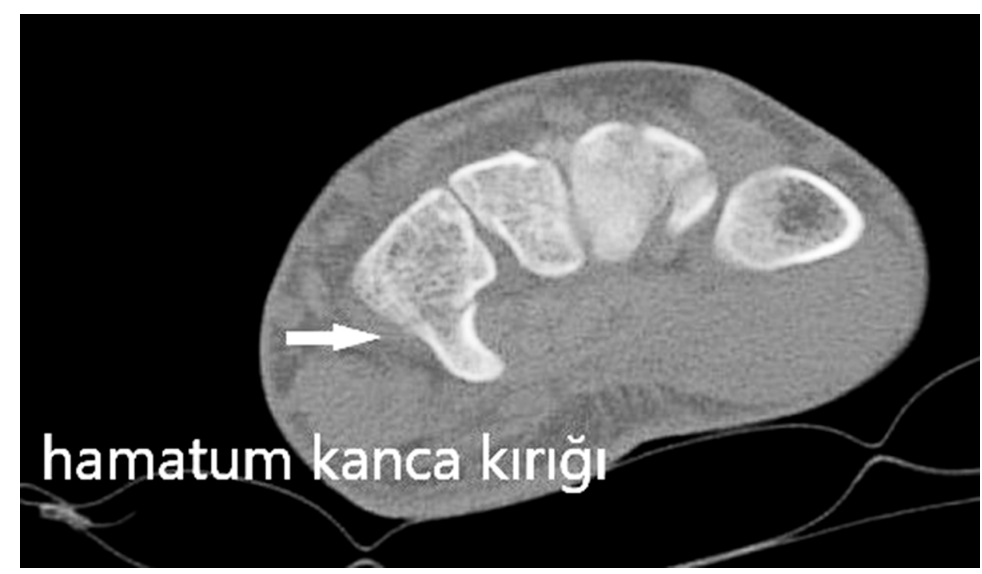

Şekil 9. Aksiyel bilgisayarlı tomografi kesitinde hamatum kanca kırığı.

\section{Karpal Kırıklar}

\section{Trikuetrum kırıkları}

Trikuetrum distalde hamatum, medialde lunatum ve volarde pisiform ile eklemleşen piramit şeklinde bir kemiktir. Skafoid kırıklarından sonra en fazla görülen karpal kemik kırıkları, trikuetrum kırıklarıdır. ${ }^{[20]}$ Trikuetrum kırıkları dorsal kortikal kırık ya da trikuetrum cisim kırığı şeklinde görülebilir. Dorsal kortikal kırıklar daha sıktır. ${ }^{[21]}$ Yaralanma sıklıkla dorsifleksiyon ve ulnar deviasyondaki açık el üzerine düşme sonrası gerçekleşir. Dorsal kortikal kırıklarda ulnar stiloid bir keski gibi trikuetruma vurarak kırığa neden olur (Şekil 8). ${ }^{[22]}$ Trikuetrum cisim kırıkları genellikle yüksek enerjili travma sonrası oluşur, sıklıkla perilunat çıkığa eşlik eder. ${ }^{[21]}$

Dorsal kortikal kırıklar genellikle 4-6 hafta alçılama ve immobilizasyon ile tedavi edilir. Fibröz kaynamama gelişse bile hastalar uzun dönemde genelde asemptomatiktir. Semptomatik kaynamama durumlarında kaynamayan fragman eksize edilebilir. Perilunat çıkıklara eşlik eden cisim kırıklarında lunotrikuetral eklem redükte edilip Kirschner telleri ile tespit edilmelidir. Yer değiştirmiş cisim kırıklarında genellikle açık redüksiyon ve internal tespit tercih edilir. ${ }^{[21]}$

\section{Hamatum kırıkları}

Hamatum kırıkları, temel olarak kanca ve cisim kırıkları olmak üzere iki gruba ayrılır.

Hamatumun kancası hipotenar eminenste (çıkıntıda), pisiformun $2 \mathrm{~cm}$ distal ve radyalinde palpe edilebilir. Parmak fleksör tendonlarına pulley olarak da görev yapar. ${ }^{[21]}$ Karpal tünelin ulnar sınırını, Guyon kanalının radyal sınııını oluşturur. Ulnar sinirin derin dalı hamatumun hemen ulnarında yer alır. ${ }^{[20]}$
Hamatum kanca kırıkları sıklıkla raket ya da sopa sporlarıyla uğraşan sporcularda görülür. ${ }^{[20]}$ Standart ön-arka, yan ve oblik grafilere ek olarak çekilen karpal tünel grafileri kırığı gösterebilse de tanı genellikle bilgisayarlı tomografiyle konur (Şekil 9).

Erken dönemde tanı koyulan yer değiştirmemiş kanca kırıkları alçı ve immobilizasyon ile takip edilebilir. Yer değiştirmiş kırıklarda ya da kaynamamış kanca kırıklarında eksizyon gerekebilir. Yer değiştirmemiş cisim kırıkları alçı ve immobilizasyon ile takip edilebilir ancak yer değiştirmiş kırıklar ve karpometakarpal eklemi ilgilendiren kırıklar perkütan pinleme ya da açık redüksiyon ve internal tespit ile tedavi edilmelidir. ${ }^{[21]}$

\section{Pisiform kırıkları}

Pisiform kırıkları nadir görülür. Özellikle aşırı ekstansiyon yaralanması şeklinde ya da hipotenar bölgeye direkt travma sonrası gelişebilir. Hastalar genelde ulnar taraflı el bilek ağrısından şikâyetçidir. Pisiform üzerinde palpasyonla hassasiyet izlenir. El bilek ön-arka ve yan grafileriyle birlikte supinasyonda oblik grafi çekilmelidir (Şekil 10). Direkt grafilerin kırığı değerlendirmede yetersiz kaldığı durumlarda bilgisayarlı tomografi kullanılabilir.

Yer değiştirmemiş kırıklar 4-6 hafta alçı ve immobilizasyon ile tedavi edilir. Parçalı kırıklarda ya da semptomatik kaynamamaya giden olgularda pisiform eksizyonu gerekir. ${ }^{[21]}$ Ulnar sinirin pisiforma yakın komşuluğu nedeniyle pisiform kırı̆̆ı sonrası ulnar sinir nöropatisi görülebilir. Bu nöropati genelde sinire direkt travma ile ilişkilidir. Yer değiştirmiş pisiform kırı̆̆ına bağlı kompresif nöropati gelişebileceğinden kırık fragmanın akut dönemde eksizyonu planlanabilir. ${ }^{[20]}$ 


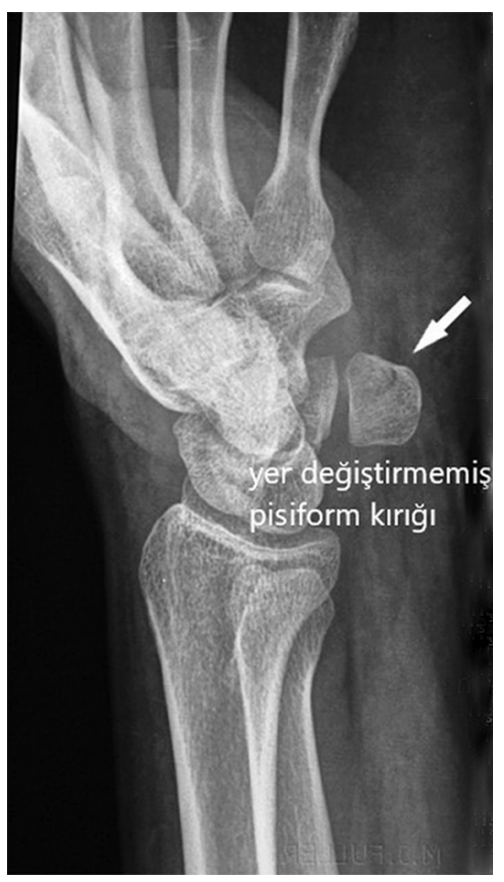

Şekil 10. Oblik grafide $30^{\circ}$ supinasyonda görülen pisiform kırığı.



Şekil 11. Pisotrikuetral artrit. Pisiform ile trikuetrum arası eklem mesafesindeki daralmaya dikkat ediniz.

\section{Pisotrikuetral Artrit}

Ulnar taraflı el bilek ağrısının nadir görülen bir nedeni de pisotrikuetral artrittir (Şekil 11). Pisiform kemik fleksör karpi ulnaris tendonu içinde yer alan, trikuetrum ile eklem yüzüne sahip bir kemiktir.

Pisotrikuetral eklem patolojilerinin yaklaşık \%90 kadarlık bir kısmını geçirilmiş travma, kronik tekrarlayan travma ya da instabiliteye bağlı gelişen sekonder osteoartrit ve fleksör karpi ulnaris tendonu entezopatileri oluşturur. Daha nadir sebepler arasında primer osteoartrit, romatoid artrit, gut artriti ve psöriatik artrit sayılabilir. ${ }^{[23]}$

Hipotenar eminenste kronik sinsi bir ağrı vardır. Genellikle pisiform kemik üzerinde palpasyonla hassasiyet mevcuttur. El bileğinin zorlu aşırı ekstansiyonunda ve dirence karşı fleksiyon ve ulnar deviasyonda ağrı artar. Standart ön-arka ve yan el bilek grafileri pisotrikuetral eklemi göstermekte yetersiz kalır. $30^{\circ}$ supinasyonda oblik grafi eklemi en iyi gösterir. ${ }^{[24]}$

Tedavide ilk olarak atel uygulanır, steroid olmayan anti-enflamatuvar ilaçlar ve kortikosteroid enjeksiyonları denenir. Cerrahi dışı tedaviye yanıtsız olgularda pisiform eksizyonu tercih edilir. Bu yöntem el bilek fonksiyonlarında güçsüzlük yaratmadan ağrıyı ortadan kaldıır. ${ }^{[23]}$

\section{Stres Kırıkları}

Distal ulna, skafoid, hamatum kancası ve metakarpların stres kırıkları atletlerde el bilek ve el ağrısının sebeplerindendir. Bu stres kırıkları sıklıkla tendon ve bağ yapışma yerlerine tekrarlayan direkt darbe veya yüklenmeler sonucu oluşur. Bu yaralanmaların en sık görüleni; beyzbol, tenis, basketbol ve ağırlık kaldırma sporlarında karşılaşılabilen distal ulna stres kırıklarıdır. Direkt grafiler normal olabilir ya da stres kırığı alanında hafif periostit şeklinde görülebilir. MR görüntüleme bu yaralanmalar için çok sensitiftir. Kemik ödemi (stres reaksiyonu) ve hipointens kırık hattını (stres kırı̆̆ mevcutsa) gösterir. Stres kırıkları 6-8 hafta istirahat ile tedavi edilir. ${ }^{[25]}$

\section{Kienböck Hastalığı}

1910 yılında Avusturyalı radyolog Dr. Robert Kienböck lunatomalazi ile ilgili radyografik değişiklikleri tanımladıktan sonra, lunat kemik osteonekrozu kendi ismiyle anılmaya başlanmıştır. Kienböck hastalığının kesin mekanizması net olarak anlaşılamamıştır. Lunat kemiğin kanlanmasında azalma, tekrarlayan mikrotravmalar, lunat kemik anatomisindeki farklılıklar ve el bilek kinematiğindeki değiş̧iklikler sorumlu tutulmaktadır.

Klasik Kienböck hastası 20-40 yaş arası ağır işte çalışan, tek taraflı tutuluma sahip erkek işçidir. Hastalar genelde yaygın el bilek ağrısı, kavrama ve yüklenmede ağrı ve azalmış el bilek eklem hareket açıklığı şikâyetiyle başvurur. Çoğu hasta travma öyküsü olmaksızın sinsi, ilerleyici ağrı tanımlar. ${ }^{[26]}$

Kienböck hastalığının tanısında MR görüntüleme altın standarttır. Radyografilerin normal olduğu erken 


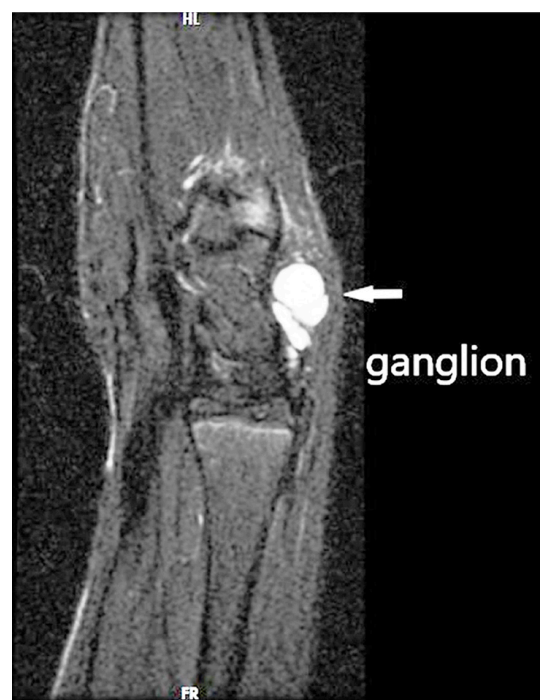

Şekil 12. Dorsal el bilek ganglionu STIR sekanslı sagittal manyetik rezonans (MR) görüntüsü.



Şekil 13. Radyal arter komşuluğundaki volar el bilek ganglionunun eksizyonu. dönemde lunat kemikteki sinyal değişiklikleri tanıda önemlidir. Kontrastlı çekimlerde lunat kemiğin kanlanması değerlendirilebilir, bu da avasküler kemiğin boyutunun saptanmasına olanak sağlar. ${ }^{[25]}$

Kienböck hastalığının erken evre tedavisi immobilizasyon ve steroid olmayan anti-enflamatuvar ilaç kullanımını içerir. Hastalığın evresine göre kor dekompresyon, radyal kısaltma, kapitat kısaltma, damarlı greftle revaskülarizasyon, proksimal sıra karpektomi, kısmi ya da total el bilek artrodezi gibi cerrahi seçenekler mevcuttur. ${ }^{[26]}$

\section{TÜMÖRLER VE TÜMÖR BENZERi OLUŞUMLAR}

\section{Ganglion}

Ganglionlar her eklemde görülebilmekle birlikte çoğunlukla el bileğinde görülen, selim lezyonlardır. \%70 kadarı dorsalde görülür ve bir pedikül aracılığıyla eklemle ilişkidedir. Bu pedikül skafolunat bağ ya da el bilek dorsal kapsülünün herhangi bir yerinden köken alabilir. Yaklaşık \%20'lik kısmı volarde görülür ve radyoskafoid eklem, skafolunat aralık, skafotrapeziyal eklem ya da metakarpotrapeziyal eklemden kaynaklanır. Yaklaşık \%10'u da fleksör tendon kılıflarından köken alır.

Elektron mikroskopisiyle yapılan incelemede ganglion duvarının rastgele yerleşmiş kollajen fibrillerinden oluştuğu görülmüştür. Duvarda sinovyal astar olmadığı için gerçek kist olarak kabul edilmezler. Yapılan analizler kistik sıvının jelatinöz kıvamda olduğunu ve temel olarak hyalüronik asit, az miktarda da globülin ve albümin içerdiğini göstermiştir. Bu sıvı sinovyal sıvidan biyokimyasal olarak farklıdır ve viskozitesi daha fazladir.

Semptomlar genelde aktivite ya da kitlenin palpasyonuyla artan el bilek ağrısı, kavramada güçsüzlük ve eklem hareket açıklığında azalmadır. Volar ganglionlar ulnar ya da median sinir veya dallarının basıya uğraması sonucu paresteziye neden olabilir. Fizik muayenede genelde sert kıvamlı, iyi sınırlı, mobil kitle saptanır. Tanıyı koymada çoğu zaman klinik yeterlidir ancak doğrulamak için ultrasonografi ya da MR görüntüleme kullanılabilir (Şekil 12).

Yaklaşık \%50'si zaman içinde kendiliğinden kaybolduğu için başlangıçta izlem düşünülebilir. Semptomatik olgularda kistin aspirasyonu tedavi için bir seçenektir ancak aspirasyon sonrası büyük oranda nüks görülür. Tedavide altın standart cerrahi eksizyondur (Şekil 13). Diğer yöntemlere göre komplikasyon oranlarının daha yüksek olduğu akılda tutulmalıdır. ${ }^{[27]}$

\section{Iyi Huylu Yumuşak Doku Tümörleri}

\section{Tendon kılıfinın dev hücreli tümörü}

El bileği ve elin ganglion sonrası en sık görülen tümörüdür. Yavaş büyüyen, sert kıvamlı, palpasyonla hassasiyet göstermeyen, fikse kitle olarak bulgu verir. Sıklıkla multinodülerdir ve komşu eklemi invaze etme eğilimindedir. Direkt radyografiler çoğunlukla normaldir. Uzun süreli kitlelerde komşu kemiğe bası nedeniyle kemikte erozyon görülebilir. Tedavisi tümörün cerrahi 
olarak çıkarılmasıdır. Cerrahi esnasında tümörün eklem içi yayılımı varsa temizlenmesi lokal tekrarın önlenmesi açısından önemlidir. ${ }^{[28]}$

\section{Hemanjiyom}

Çoğalmakta olan damarlardan oluşur ve genellikle ilk birkaç yaşta ortaya çıkar. Tipik olarak 1 seneye kadar uzayabilen bir hızlı büyüme evresinin ardından gerileyip zaman içinde kaybolur. Yaklaşık \%70 kadarı 7 yaşına kadar kendiliğinden kaybolur. Yüzeyel olanları genelde iyi sınırlı kitleler olarak izlenir. Derin yerleşimli olanlar arteriyovenöz malformasyonla karışabilir. Tanıda MR anjiyografi ya da anjiyografi yardımcıdır. Çocukluk çağında görülenlerin tedavisinde gözlem ve aileyi bilgilendirmek yeterlidir. Kanama, ülserasyon, enfeksiyon ve koagülopati gibi komplikasyonlar görülebilir. Komplikasyonlar semptomatik olarak tedavi edilir. Spontan gerilemeyen, semptomatik kalan ve sinir basısı vb. fonksiyon bozukluğu oluşturan tümörler için cerrahi eksizyon yapılabilir. Nüks ihtimalinin yüksekliği hastaya bildirilmelidir. ${ }^{[28]}$

\section{Kistik Lezyonlar}

\section{Anevrizmal kemik kisti}

El bilek ve el çevresinde de görülebilen selim ancak lokal agresif bir lezyondur. Adolesan ve genç erişkinlerde daha sık görülür. Konvansiyonel radyografilerde kortikal destrüksiyona yol açan litik, ekspansil lezyon izlenir. MR görüntülemede sıvı-sıvı seviyeleri tanıya yardımcıdır. Tedavide küretaj ve otogreft ya da allogreft ile greftleme genellikle yeterlidir. Nüks sıktır ve tekrar küretaj ve greftleme ile tedavi edilir.

\section{Basit kemik kisti}

El bilek ve elde çok nadir görülür. Klinik ve radyolojik özellikleri proksimal humerus ve femurdakine benzerdir. Sıklıkla başka bir problem için çekilen direkt grafilerde rastlantısal olarak ya da patolojik kırık ile tanı alır. Tedavide gözlem, lezyonun aspirasyonu sonrası lezyon içine kortikosteroid enjeksiyonu veya küretaj ve greftleme gibi seçenekler mevcuttur. ${ }^{[28]}$

\section{Kemik Oluşturan Tümörler}

Osteoid osteoma ve osteoblastoma kemik oluşturan tümörlerdir.

\section{Osteoid osteoma}

Osteoid osteomada en sık şikâyetler ağrı ve lokal hassasiyettir. Ağrı geceleri daha fazladır ve genellikle steroid olmayan anti-enflamatuvar tedaviye yanıt verir. Klasik radyografik görünüm $1 \mathrm{~cm}$ 'den küçük, reaktif sklerozla çevrili ve santral yerleşimli radyolusent lezyondur. Bu lezyon nidüs olarak adlandırılır.
Konvansiyonel radyografilerin yaklaşık \%25'inde nidüs görülemez. Bu nedenle bilgisayarlı tomografi tanıya yardımcıdır. Tedavi nidüsun cerrahi olarak çıkarılmasıdır. Operasyon sonrası devam eden ağrı, nidüsun tam çıkarılamamasını işaret edebilir. Bazı hastalarda osteoid osteoma kendiliğinden kaybolabilir, bu nedenle steroid olmayan anti-enflamatuvar tedaviye yanıtlı hastalarda cerrahi dışı takip denenebilir. ${ }^{[28]}$

\section{Osteoblastoma}

Histolojik olarak osteoid osteomaya benzer ancak bazı farklılıkları mevcuttur. Boyut olarak daha büyüktürler (genelde $2 \mathrm{~cm}$ 'den büyük) ve steroid olmayan anti-enflamatuvar tedaviye yanıt vermezler. Bu lezyonlar genelde büyüme eğilimindedir. Cerrahi eksizyon küratiftir. ${ }^{[28]}$

\section{Kemik Yıkımı Yapan Tümörler \\ Kemiğin dev hücreli tümörü}

Selim ancak lokal agresif özellikte bir tümördür. En sık yakınmalar ağrı ve şişliktir. Direkt radyografilerde radyolusent, epifize uzanan, sınırları belirsiz, ekspansil özellikte lezyon görülür. Sıklıkla kortikal yıkım ve çevre yumuşak dokulara yayılım mevcuttur. Küretaj ve greftleme sonrası nüks sık olsa da en azından bir kez denenmelidir. Tekrarlayan tümörde enblok rezeksiyon ve oluşan defektin otogreft ya da allogreft ile doldurulması gereklidir. ${ }^{[28]}$

\section{NÖROVASKÜLER HASTALIKLAR}

\section{Ulnar Tünel Sendromu (Guyon Kanalı Sendromu)}

Ulnar sinir tuzaklanması en sık dirsekte olmakla birlikte, el bileğinde de görülebilir. Ulnar sinirin el bileğinde tuzaklanmasına ulnar tünel sendromu adı verilir. Kübital tünel sendromunda olduğu gibi el ve parmaklarda duyusal ve motor defisitlere yol açabilir. 4. parmağın ulnar yarısında ve 5. parmakta parestezi görülür. Dorsal ve palmar kutanöz dallar, sinir ulnar tünele girmeden önce ayrıldığı için avuç içinin ulnar kısmı ve el sırtının duyusu korunur.

Jean Casimir Felix Guyon 1861 yılında ulnar sinirin hipotenar bölgedeki seyrini ve dallanmalarını tanımlamıştır (Şekil 14). ${ }^{[29]}$ Guyon'un ulnar sinirin potansiyel sıkışma bölgesi olarak tanımladığı bu boşluk ulnar tünel ya da Guyon kanalı olarak adlandırılır. Gross ve Gelberman, ulnar tünelin distal kısmını ulnar sinirin motor ve duyu komponentlerinin bulunmasına göre üç zona ayırmıştır. ${ }^{[29]}$ Bu zonların tanınması, hastanın semptom ve bulgularına göre sıkışma bölgesinin belirlenmesi açısından önemlidir.

1. zon tünelin ilk $3 \mathrm{~cm}$ 'lik kısmıdır ve ulnar sinirin bifurkasyon öncesi bölümünü bulundurur. Ulnar sinirin en fazla sıkıştığı zondur. Ulnar sinirin bu zondaki 


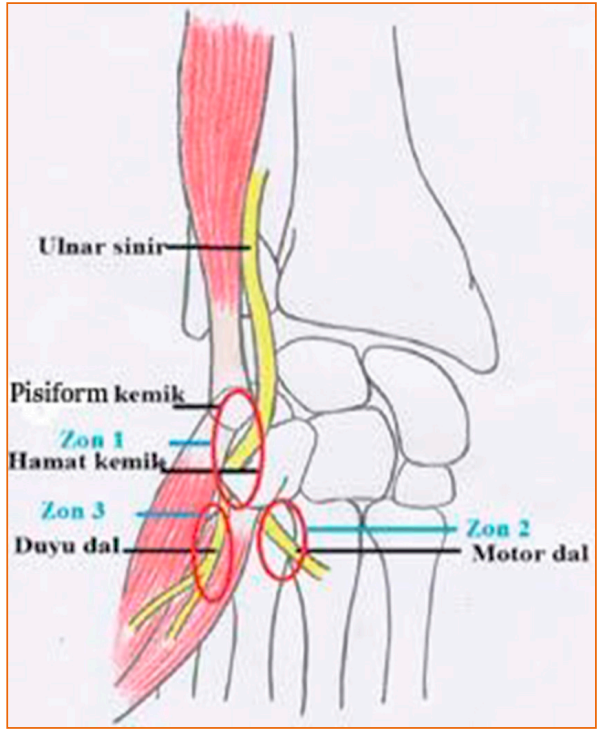

Şekil 14. Ulnar sinirin Guyon kanalındaki seyri.



Şekil 15. Guyon kanalında bifurkasyon öncesi ulnar sinire bası yaparak motor ve duyusal fonksiyon bozukluğuna neden olan ganglion kistinin operasyon esnasındaki görüntüsü. sıkışması parestezi ve intrinsik kas defisitiyle bulgu verir. Ulnar sinir, volarde volar karpal bağ ve dorsalde transvers karpal bağ arasında sıkışır. Ganglion kistleri, hamatum kancasının kırıkları, travma sonrası yapışıklıklar ve anormal kaslar 1. zondaki sıkışmanın başlıca sebepleridir (Şekil 15). Ulnar sinirin bifurkasyonu sonrası derin motor dalı hamatumun dorsal ve radyaline doğru bir rota izleyerek hipotenar kasların fibröz arkının derinine ilerler. Bu bölge ulnar tünelin 2. zonunu oluşturur ve buradaki sıkışma sadece motor fonksiyon defisitine neden olur, duyu korunmuştur. 1. zonda olduğu gibi en sık sıkışma nedeni ganglion kistleridir. Kırıklar ve pisohamat bağın kalınlaşması 2. zondaki ulnar nöropatinin diğer nedenleridir. 3. zon ulnar sinirin hipotenar kasların fasyasının palmarında yer alan yüzeyel duyu dalını içerir. Bu zondaki sıkışmalar duyusal bozukluklara sebep olur ve en sık ulnar arter anevrizması ve trombozuna bağlı meydana gelir.

Hafif ulnar tünel sendromu olguları atel uygulaması, anti-enflamatuvar ilaçlar ve aktivite modifikasyonu ile cerrahi dışı tedavi edilebilir. Özellikle yer kaplayan lezyonlara sekonder gelişen daha ciddi olgularda ve uzun süreli cerrahi dışı tedaviye yanıt alınamayan olgularda cerrahi tedavi endikasyonu vardır. Ulnar intrinsik kaslarda denervasyon, atrofi, güçsüzlük ve uzun süreli ulnar duyusal nöropati varlığı cerrahi tedavi endikasyonlarıdır.

Ulnar tünel sendromunun cerrahi tedavisinde ön kol distalinden başlayıp pisiform ve hamatum arasından tenar çizgiye paralel seyreden ve el bileğini oblik geçen bir kesi yapilır, bu kesi distal ve proksimale bir miktar genişletilir. Proksimalde antebrakiyal fasya kesilerek zon 1 gevşetilir. Ulnar sinir distale doğru izlenir ve volar karpal bağ gevşetilir. Ulnar arter, anevrizma veya trombüs açısından izlenir. Hipotenar kasların fibröz arkı açılarak derinindeki motor dal dekomprese edilir. Kitle, fibröz bant, anormal bir kas veya kemik fragman varsa, eksize edilir. Yüzeyel duyu dalı fibröz ark ve hipotenar kasların yüzeyelinde seyreder. Eldeki sıkışmalar için, derin motor dal takip edilir. Insizyon, adduktor pollisis kasına giren motor dala kadar genişletilir. Yer kaplayan lezyonların çıkarılması, hastaların büyük çoğunda klinik düzelme sağlamaktadır (Şekil 16). Komplikasyonlar arasında ise, en çok ulnar sinir veya arter dallarının yaralanması sayılabilir. ${ }^{[30]}$

Ulnar sinirin yüzeyel duyusal dalı el sırtının ulnar kısmının ve 4 ve 5. parmakların proksimal ve orta falankslarının dorsalinin duyusunu alır. Yüzeyel seyrinden dolayı penetran ve künt travma sonrası ya da iyatrojenik olarak yaralanabilir. Ayrıca el bilek fleksiyonu ve ön kol pronasyonu gerektiren işlerde çalışanlarda, sıkı saat takma sonrası, kelepçe takılmasına bağlı olarak ya da karate sporuyla uğraşanlarda elin ulnar kısmının sert yüzeylere tekrarlayan darbelerinin sonucu bu sinirin izole nöropatisi bildirilmiştir. ${ }^{[31]}$

İhmal edilmiş ulnar sinir yaralanmaları sonrası nöromalar gelişebilir. Cerrahi esnasında devamlılı̆ı olan bir nöroma varlığında elektromiyografi, ultrason ve ameliyat sırasında sinir aksiyon potansiyeli çalışmaları yaralanmanın derecesini ve tedavi şeklini belirlemeye yardımcıdır. Nöroma eksize edildikten sonra uç uca onarım yapılır. Uç uca onarım yapılamayacak kadar büyük defekt varsa sinir grefti ile onarım planlanabilir. 




Şekil 16. Şekil 15'teki ganglionun eksizyonu sonrası görüntü.

Proksimaldeki yaralanmalar için distal sinir transferleri yapılabilir. Sinir onarımına rağmen kalıcı motor fonksiyon bozukluğunda tendon transferleri ikinci aşamada düşünülmesi gereken yöntemdir. ${ }^{[32]}$

\section{Hipotenar Çekiç Sendromu}

Hipotenar çekiç sendromu ulnar arterin tıkanması ya da anevrizmasına bağlı gelişen, nadir görülen, zamanında tanınıp tedavi edilmezse amputasyona kadar varan ciddi komplikasyonlara neden olabilen bir hastalıktır. Hipotenar kaslara akut künt travma, vibratuvar travma ya da kronik tekrarlayan travma alan kişilerde görülür. Hipotenar kaslara gelen tekrarlayıcı darbeler ulnar arterin yüzeyel dalının hasarlanmasına neden olabilir. Tromboze ulnar arterden atan dijital emboliler parmaklarda iskemi ya da nekroza yol açabilir.

Hipotenar çekiç sendromu elde veya parmaklarda renk değişiklikleri, soğuk intoleransı, parmak uçlarında minör ülserasyonlar ve nekrotik alanlarla karakterizedir. Semptomların ciddiyeti tıkanık olan segmentle ve derin ve yüzeyel palmar arklar arasında kollaterallerin varlığıyla ilişkilidir. Ultrasonografi, bilgisayarlı tomografi ve MR görüntüleme tanıya yardımcı yöntemler olmakla birlikte, tanıda altın standart anjiyografidir. Başlangıç tedavisi olarak hastalığı tetikleyen aktivitelerden kaçınılmalı, sigara içiliyorsa mutlaka bırakılmalıdır. Çoğu hastada cerrahi dışı tedaviye yanıt iyidir. Medikal tedavide kalsiyum antagonistleri, tip A botulinum toksini, beta blokerler, silostazol, nifedipin ve antitrombotik ajanlar kullanılabilir. Cerrahi dışı tedaviye yanıt vermeyen hastalarda cerrahi tedavi bir seçenektir.
Anevrizmatik ya da tromboze segment tamamen çıkarılarak greftleme uygulanır. Bu tedavi yöntemlerine proksimal servikotorasik sempatektomi ya da periferal periarteriyel sempatektomi eklenebilir. ${ }^{[33]}$

\section{KAYNAKLAR}

1. Garcia-Elias M. Tendinopathies of the extensor carpi ulnaris. Handchir Mikrochir Plast Chir 2015;47(5):312-5. Crossref

2. Wood MB, Dobyns JH. Sports-related extraarticular wrist syndromes. Clin Orthop Relat Res 1986;(202):93-102. Crossref

3. Futami T, Itoman M. Extensor carpi ulnaris syndrome. Findings in 43 patients. Acta Orthop Scand 1995;66(6):5389. Crossref

4. Ruland RT, Hogan CJ. The ECU synergy test: an aid to diagnose ECU tendonitis. J Hand Surg Am 2008;33(10):1777-82. Crossref

5. Hajj AA, Wood MB. Stenosing tenosynovitis of the extensor carpi ulnaris. J Hand Surg Am 1986;11(4):519-20. Crossref

6. Kip PC, Peimer CA. Release of the sixth dorsal compartment. J Hand Surg Am 1994;19(4):599-601. Crossref

7. Inoue G, Tamura Y. Recurrent dislocation of the extensor carpi ulnaris tendon. Br J Sports Med 1998;32(2):172-4. Crossref

8. Allende C, Le Viet D. Extensor carpi ulnaris problems at the wrist--classification, surgical treatment and results. J Hand Surg Br 2005;30(3):265-72. Crossref

9. Rosner JL, Zlatkin MB, Clifford P, Ouellette EA, Awh $\mathrm{MH}$. Imaging of athletic wrist and hand injuries. Semin Musculoskelet Radiol 2004;8(1):57-79. Crossref

10. Shin AY, Deitch MA, Sachar K, Boyer MI. Ulnar-sided wrist pain: diagnosis and treatment. Instr Course Lect 2005;54:115-28. https://pubmed.ncbi.nlm.nih.gov/15948439/

11. Budoff JE, Kraushaar BS, Ayala G. Flexor carpi ulnaris tendinopathy. J Hand Surg Am 2005;30(1):125-9. Crossref

12. Phillips SG. An Evidence-based review of overuse wrist injuries in athletes. Orthop Clin North Am 2020;51(4):499-509. Crossref

13. Topper SM, Wood MB, Ruby LK. Ulnar styloid impaction syndrome. J Hand Surg Am 1997;22(4):699-704. Crossref

14. Giachino AA, Mclntyre AI, Guy KJ, Conway AF. Ulnar styloid triquetral impaction. Hand Surg 2007;12(2):123-34. Crossref

15. Watanabe A, Souza F, Vezeridis PS, Blazar P, Yoshioka H. Ulnar-sided wrist pain. II. Clinical imaging and treatment. Skeletal Radiol 2010;39(9):837-57. Crossref

16. Cerezal L, del Piñal F, Abascal F. MR imaging findings in ulnar-sided wrist impaction syndromes. Magn Reson Imaging Clin N Am 2004;12(2):281-99, vi. Crossref

17. Bell MJ, Hill RJ, McMurtry RY. Ulnar impingement syndrome. J Bone Joint Surg Br 1985;67(1):126-9. Crossref

18. Wolfe SW, Garcia-Elias M, Kitay A. Carpal instability nondissociative. J Am Acad Orthop Surg 2012;20(9):575-85. Crossref

19. Nikci V, Doumas C. Calcium deposits in the hand and wrist. J Am Acad Orthop Surg 2015;23(2):87-94. Crossref

20. Papp S. Carpal bone fractures. Hand Clin 2010;26(1):11927. Crossref

21. Christie BM, Michelotti BF. Fractures of the carpal bones. Clin Plast Surg 2019;46(3):469-77. Crossref 
22. Garcia-Elias M. Dorsal fractures of the triquetrum-avulsion or compression fractures? J Hand Surg Am 1987;12(2):266-8. Crossref

23. Paley D, McMurtry RY, Cruickshank B. Pathologic conditions of the pisiform and pisotriquetral joint. J Hand Surg Am 1987;12(1):110-9. Crossref

24. Carroll RE, Coyle MP Jr. Dysfunction of the pisotriquetral joint: treatment by excision of the pisiform. J Hand Surg Am 1985;10(5):703-7. Crossref

25. Llopis E, Restrepo R, Kassarjian A, Cerezal L. Overuse Injuries of the Wrist. Radiol Clin North Am 2019;57(5):957-76. Crossref

26. Rioux-Forker D, Shin AY. Osteonecrosis of the Lunate: Kienböck Disease. J Am Acad Orthop Surg 2020 15;28(14):570-84. Crossref

27. Gude W, Morelli V. Ganglion cysts of the wrist: pathophysiology, clinical picture, and management. Curr Rev Musculoskelet Med 2008;1(3-4):205-11. Crossref
28. Plate AM, Lee SJ, Steiner G, Posner MA. Tumorlike lesions and benign tumors of the hand and wrist. J Am Acad Orthop Surg 2003;11(2):129-41. Crossref

29. Gross MS, Gelberman RH. The anatomy of the distal ulnar tunnel. Clin Orthop Relat Res 1985;(196):238-47. Crossref

30. Sahin MS, Altun S, Kafa B. Kübital tünel sendromu ve ulnar sinirin diğer tuzak nöropatileri. TOTBID Dergisi 2015;14(6):555-65. Crossref

31. Garibaldi SG, Nucci A. Dorsal cutaneous branch of ulnar nerve: an appraisal on the anatomy, injuries and application of conduction velocity studies in diagnosis. Arq Neuropsiquiatr 2000;58(3A):637-41. Crossref

32. Woo A, Bakri K, Moran SL. Management of ulnar nerve injuries. J Hand Surg Am 2015;40(1):173-81. Crossref

33. Şahin MŞ, Özyürekoğlu T, Çakmak G. Hypothenar hammer syndrome: a case series and literature review. Eklem Hastalik Cerrahisi 2015;26(1):11-5. Crossref 